Article

\title{
Comparative Analysis of Private Labels-Private Labels from the Point of View of a Millennial Customer in Slovakia, Czech Republic and Hungary
}

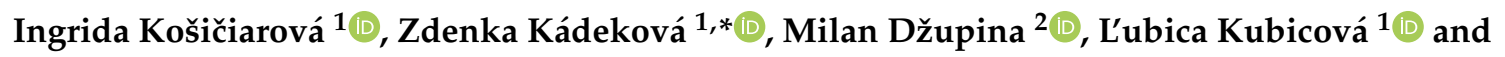 \\ Marek Dvořák ${ }^{3}$ (1) \\ 1 Department of Marketing and Trade, Faculty of Economics and Management, Slovak University of \\ Agriculture in Nitra, 94911 Nitra, Slovakia; ingrida.kosiciarova@gmail.com (I.K.); \\ kubicova.lubka@gmail.com (L'.K.) \\ 2 Department of Mass Media Communication and Advertising, Faculty of Philosophy, Constantine the \\ Philosopher University in Nitra, 94911 Nitra, Slovakia; mdzupina@ukf.sk \\ 3 Department of Trade and Finance, Faculty of Economics and Management, Czech University of Life \\ Sciences Prague, 165000 Prague, Czech Republic; dvorakmarek@pef.czu.cz \\ * Correspondence: zdenka_kadekova@yahoo.com; Tel.: +421-37-641-4171
}

Received: 27 October 2020; Accepted: 20 November 2020; Published: 24 November 2020

\begin{abstract}
The present paper is focused on the issues of private labels, their establishment, perception and preference by selected groups of respondents, namely consumers under the age of 25 and also inhabitants of selected V4 countries (Slovakia, Hungary and Czech Republic). An anonymous questionnaire survey was chosen as the main research method. A total of 3038 respondents aged under 25 participated-1064 respondents were from Slovakia, 973 from Hungary and 1001 from Czech Republic. This research method was subsequently supplemented with selected statistical methods evaluated in the XL Stat statistical program, SAS Enterprise Guide 7.1 and SAS 9.4, where hypotheses were examined by Pearson's Chi-Square Test, Mantel-Haenszel Chi-square test, Cramer's V contingency coefficient, Pearson's correlation coefficient, Friedman's test, Kruskal-Wallis test, Correspondence analysis and Phi Coefficient. The results of the survey can be perceived more than positively as most of the respondents declared that they knew the concept of private labels; more than $80 \%$ of respondents buy them either regularly or sporadically; just over $32 \%$ of respondents explicitly prefer them in their purchases and in terms of the perception of the quality, almost $75 \%$ of respondents think the quality of private label products is comparable to that of traditional brands.
\end{abstract}

Keywords: private labels; consumers; perception; preference; quality

\section{Introduction}

In the modern market economy where the supply exceeds demand [1], companies are facing a number of challenges due to the dynamic environment [2,3]. The constant growth of competition is forcing them to look for new sources of competitive advantages [4], from which the winners are the customers who benefit from the increase in the price competition [5] and production efficiency [6], because they can buy goods cheaper [7]. It is important to keep in mind the redistribution of resources. Resource misallocation has resulted in differences in intereconomy total factor productivity. However, the factors driving different levels of resource misallocation still need to be investigated [8]. Unfortunately, currently, the company's value and performance are not dependent on the value of their property, production or equipment, but rather depends on how it is perceived by the public and what name it has. For this reason, companies are looking for new opportunities to reach new potential customers and make them loyal customers who will regularly buy their products and services, 
which will not only strengthen their competitive advantage but also improve their perceived name. In addition, increasingly, companies must, as part of their business activities, face certain risks that may lead to a reduction in the value of the organization, its overall weakening or even may be the reason for its decline [9]. While the branding can be seen as a strategy or mechanism whose key function is to differentiate products and services with a view to ensuring competitiveness [10], there has been a significant shift in terms of consumer preferences to private labels over the last two decades [11] characterized by a slightly different strategy but with similar goals.

The present paper deals with the issue of private labels from the consumers' point of view. It is the authors' response to the actual situation and to the results of other authors' research such as "Study on the economic value of EU quality schemes geographical Indications (GI) and traditional specialties guaranteed (TSG)" [12], for the European Commission, Directorate General for Agriculture and Rural Development, which took place in the EU in 2019. Based on interviews with product managers, the authors realized the gap in the market that needs to be covered and which can be used to better help not only retailers but also the producers themselves. Precisely for the above reason, the aim of the paper is to describe the issues of private labels and analysis of possible differences between knowledge, perception and preference of private labels by selected groups of respondents, i.e., respondents under 25 years of age and population of selected V4 countries.

\section{Theoretical Background}

The current retail revolution, which as it is reported by [13], has and will have a significant impact on the food industry around the world and is characterized primarily by the development of one global phenomenon, namely private labels [14-16].

The private label, also referred to in the literature and various sources as the seller, retailer, shop or own brand [17], is a term derived from the English words "private label", "store brand", "own label" products and include products and services that are manufactured or provided for a particular vendor for sale in its store under its own name or its own name [18,19]; thus giving up its own brand [20,21] with the aim of expanding the offered range of goods, increasing profitability, meeting customer needs and promoting production [22].

Consumers are currently in an increasingly competitive and dynamic market environment [23,24], where the brand itself is either losing its weight or strengthening it. Here the possibility for private labels can be seen, which can become a perfect alternative to traditional brands, bringing several benefits not only to the consumer and retailer but also to the supplier themselves, especially in increasing sales volume, lower communication and logistics costs and options to enter new markets [25-27]. Private labels are generally considered to be more profitable not only by lower production costs but also by lower costs for research and development, promotion, sales promotion, advertising and physical distribution [28]. This is mainly due to the use of branded products and services as a model and inspiration [29], which in turn translates into the price of the sold products and services and means that a private label trader may charge a lower price to his products and services while achieving a higher profit margin.

Reference [30] present interesting research results. Their research has documented the asymmetric nature of promotions between weaker (e.g., private labels) and stronger (e.g., national) brands [31,32]. This has led to suggestions that private label promotions make little sense since they are relatively ineffective in stealing share from national brands. By [33], the presence of large national brands has a positive spillover effect on the popularity of private labels in fashion social media and ultimately influences sales of private label products. The results add to our understanding of the impact of Business-to-Business (B2B) social media marketing on brand competition in the fashion industry. Reference [34] published a study to predict customer lifetime value for hypermarket private label products. The study was conducted on a total of 330 respondents. According to the authors, store awareness constituted a positive factor influencing private label image. Price/value constituted a factor positively influencing private label image. In particular, compared with customers perceiving low 
image fit, the positive effect of price/value on private label image was stronger for customers perceiving high image fit.

Despite the fact that the US is considered to be the "birthplace" of private labels, their history dates back to the 19th century when appeared the first private label of The Great Atlantic and Pacific Tea Company (A\&P, which was selling coffee and tea), which launched its own baking powder brand in 1880 [35]; in the case of Europe, we can speak of a later, but more extensive and faster development and establishment of the consumer market. While in the US the share of the private label purchases in household expenditures is $18 \%$ on average, for Europe it is almost double, if not triple. In addition, this is indeed a noticeable increase, as in 2008 these proportions of private label purchases in household expenditures were 'only' 23\% in Europe, 16\% in the USA and 19\% in Canada [13]. This difference can be caused not only by the different cultural environment but also by the financial background of households in individual countries of the world. The results of several surveys showed significant differences in purchasing behavior not only in terms of respondents' gender, age and education but also in terms of their net money income [36]. Reference [37] investigated the involvement of private labels in digital mediation. According to the authors in addition, online retailers' dynamic pricing can cause spikes in demand causing stock-outs in both online and offline sales points [38], which may once again result in brand erosion [39,40]. Ultimately, this intense price competition distorts consumers' price perceptions, potentially jeopardizing premium brands in favor of economy brands and private labels, akin to the effects observed in price-wars in the grocery sector.

The private label priority is, in addition to gaining the competitive advantage, also providing the right alternative to purchasing for more cost-sensitive consumers, their higher preference, as well as buying in individual countries of the world, may be due to this fact. While in 2017 all four V4 countries have increased their share compared to the previous year 2016, in 2018 only two countries-Hungary (up to 29\%) and the Czech Republic (up to 22\%) - can speak of this increase. In the case of Slovakia, a slight decrease can be observed, as, in 2018, the share of private label chain purchases in household expenditures was "only" at the level of $26 \%$, which means a decrease by $1 \%$ [41,42].

In the comparison of the years 2017 and 2018 it can stated, that the share of private label chain purchases in household expenditures increased compared to 2017 in 12 out of 19 European countries and were equal or higher than $30 \%$ in 17 European countries. Private label market share in the largest retail market in Germany was $46 \%$ (the highest level so far) and in countries such as Spain and Switzerland, it continued to account for half of the products sold (52 and 50\%). For other European countries, we can speak of a similarly significant quantitative shift as for Germany, as for the United Kingdom, it was up to $46 \%$, for France $30 \%$, for Turkey $26 \%$, for Sweden, Norway and Finland, as well as Poland, Hungary, the Czech Republic and Slovakia by more than $30 \%$ (in this case we can speak of a leader in the form of Hungary, where the share has risen to $34 \%$ ) and in Austria up to $43 \%$ share [43,44]. Up to the situation in 2019 it can be concluded, that while in Germany and Switzerland, the situation is almost unchanged, the private label share in household purchases is between 45 and $49 \%$, in Sweden, Norway, Denmark, The Netherlands and Turkey can be referred to as further quantitative shifts as there is an increase of one to two percentage points in all these countries [45].

The development and subsequent establishment of private labels have brought about a number of structural changes that affect the sector as a whole, not only retailers but also producers and consumers themselves. Retailers embarked on a clear market segmentation strategy through their private labels, in close alignment with the price, product category and benefits sought by consumers [46], creating the multiple scenarios in which a wide range of private labels can be implemented, so private labels are no longer exclusively market segments based almost exclusively on price but are brands that offer unmatched value in exchange for money and are attractive to a new kind of consumer who is focused on both price and quality [47].

Success in the present highly competitive environment is determined by the vendors' ability to understand the customer and their needs and desires at the right place and time. According to [48], consumers have incredible power because their behavior has an enormous impact not only on the 
business, but also on the society. This is true both, for the entertainment and food industry, it does not matter what country or segment the company is active in, the customer attitudes and behavior are of utmost importance to it. The consumers drive consumption and purchasing behavior and they are the basis of trade as such, because if there's nobody to buy, it does not make any sense to sell [49].

Despite the fact, that there have been a few studies that have suggested that consumer needs, interests and attitudes vary with age and that younger consumers have a more positive attitude toward innovation, ICT adoption, computing, online shopping and m-shopping (e.g., [50-53]). This segment of consumers represent potential customers, with a high potential to become loyal customers (e.g., [54-56]), but the fact is, that almost none of the researches have focused on this segment of customers in the field of private labels, the only exceptions in this field are our own previous research, where we have focused on the given issue from the given point of view (e.g., [57-60]).

The originality of our research and thus of the presented contribution lies not only in the field of private label research from the point of view of the "young generation" of respondents but above all in its extension and application to selected V4 countries.

\section{Materials and Methods}

As it was mentioned in the Introduction, the present paper and its research is the authors' response to the actual situation and to the results of other authors' research "Study on the economic value of EU quality schemes geographical Indications (GI) and traditional specialties guaranteed (TSG)" [12], for the European Commission, Directorate General for Agriculture and Rural Development, which took place in the EU in 2019. Based on interviews with product managers, the authors' realized the gap on the market and the importance of the "young" generation of consumers, who can represent the potential consumers and by the time the loyal consumers of private labels. The aim of submitted paper is to describe the issues of private labels and analyze possible differences between knowledge, perception and preference of private labels by selected groups of respondents, i.e., respondents under 25 years of age and from one of the selected V4 countries. Consumers under the age of 25 became the subject of the survey as they represent potential consumers of private label products, and these consumers were from three V4 countries, namely Slovakia, Hungary and the Czech Republic. Private labels from the perspective of knowledge, preferences and perception by selected groups of respondents became the subject of the research. An anonymous questionnaire survey was conducted in the period from June to December 2019 and was chosen as the main research method.

The questionnaire survey consisted of a total of 14 questions (and one subquestion, which was addressed to those respondents only who answered positively in the previous question), conceived as closed, where the respondents had the possibility to choose one of the above-mentioned options, indicating their opinion on a scale of 1 to 5 , with 1 representing the most and 5 the least; and one open question, where they should describe in their own words the term private labels (note: the question was formulated from the need to know the knowledge of the term by respondents). These questions were focused on the issue of private labels, namely the knowledge of the concept of purchase the private labels and preference for private label products over traditional brands, perception the comparability of the quality of private label products, as well as the factors that discourage from purchase and leading to purchase the private label products.

A total of 3038 respondents (in the age under 25 years) took part in the survey, while the representation for the V4 countries was as follows: 1064 respondents from Slovakia, 973 respondents from Hungary and 1001 respondents from the Czech Republic. The above-mentioned sample of respondents was possible with $95 \%$ confidence level and $4 \%$ error tolerance ranges, at $99.7 \%$ confidence level and $5 \%$ margin of error should be considered as representative as $n \geq 600.25, n \geq 900$.

In the implementation and construction of our research, we relied on "domestic" research, e.g., [61-66]; foreign research e.g., [47,67-73], where they similarly focused on an anonymous questionnaire survey implemented and disseminated online and where they relied on the reliability of 
their data. Based on the above, it can be said that our data and results are not only reliable but also relevant and statistically significant.

As can be seen from Table 1 below, the representation of the different categories of respondents was roughly the same for all 3 surveyed countries, so it can be said that most respondents were women $(58.76 \%)$, which may be largely related to the fact that according to several researches, most of the purchases are made by women. In terms of other classification characteristics of respondents, it can be said that most respondents were represented in the categories of employed (60.37\% of respondents), respondents with completed university education II. Grade (38.38\% of respondents), net monthly income of household ranged from EUR 1101 to EUR 1500 (39.86\% of respondents), respectively household with three members (36.18\% of respondents).

Table 1. Characteristics of respondents; Source: Results of research.

\begin{tabular}{|c|c|c|c|}
\hline & \multicolumn{3}{|c|}{ Number } \\
\hline & Slovakia & Hungary & The Czech Republic \\
\hline \multicolumn{4}{|c|}{ Category of respondents } \\
\hline Male & 494 & 360 & 399 \\
\hline Female & 570 & 613 & 602 \\
\hline \multicolumn{4}{|c|}{ Educational structure of respondents } \\
\hline Primary education & 5 & 60 & 3 \\
\hline Secondary education without A level & 111 & 5 & 66 \\
\hline Secondary education with A level & 390 & 401 & 281 \\
\hline University education I. grade & 245 & 17 & 253 \\
\hline University education II. grade & 305 & 485 & 376 \\
\hline Other & 8 & 5 & 22 \\
\hline \multicolumn{4}{|c|}{ Economic activity of respondents } \\
\hline Student & 98 & 126 & 77 \\
\hline Employed & 591 & 600 & 643 \\
\hline Unemployed & 14 & 49 & 0 \\
\hline Self-employed & 217 & 133 & 140 \\
\hline Maternity leave & 59 & 40 & 90 \\
\hline Retired & 63 & 49 & 49 \\
\hline \multicolumn{4}{|c|}{ Net money income of the household per month } \\
\hline Up to EUR 500 & 0 & 91 & 7 \\
\hline EUR 501-800 & 35 & 140 & 77 \\
\hline EUR 801-1.100 & 182 & 238 & 259 \\
\hline EUR 1.101-1.500 & 567 & 231 & 413 \\
\hline More than EUR 1.501 & 280 & 273 & 245 \\
\hline \multicolumn{4}{|c|}{ Number of household's members } \\
\hline 1 member & 15 & 61 & 29 \\
\hline 2 members & 259 & 252 & 266 \\
\hline 3 members & 476 & 238 & 385 \\
\hline 4 members & 286 & 380 & 279 \\
\hline Others & 28 & 42 & 42 \\
\hline Total number of respondents & 1.064 & 973 & 1.001 \\
\hline \multicolumn{3}{|c|}{ Total } & 3.038 \\
\hline
\end{tabular}


Due to the need for a deeper analysis of the data obtained in the submitted paper were used and interpreted via several contingency tables processed in Excel and its complement XL Stat, in the SAS Enterprise Guide 7.1. and SAS 9.4., in which the individual dependencies and hypotheses were subsequently verified using the following tests and technics of Pearson's Chi Square Test, Mantel-Haenszel Chi-square test, Cramer's V contingency coefficient, Pearson's correlation coefficient, Friedman's test, Kruskal-Wallis test, Phi Coefficient and Correspondence analysis.

\section{Results and Discussion}

As stated in the methodology, the aim of the paper was to identify and analyze possible differences between the knowledge, perception and preference of private labels by selected groups of respondentsinhabitants of selected V4 countries: Slovakia (1064 respondents), as in the case of purchasing and preference of private label products within Europe, Slovakia is one of the leaders in this field, followed by Hungary (973 respondents), because this country represents V4 countries in recent years and the absolute leader in terms of private label products preference by its inhabitants and the Czech Republic (1.001 respondents) due to the historical context and dependencies on the basis of which it can be referred to as a "sister" country (note: until December 1992 Czechoslovakia, which peacefully divided into two independent states-the Czech Republic and Slovakia); and we have wondered if there are fundamental differences in the perception and knowledge of private labels between Slovak and Czech respondents.

The results of our questionnaire survey show a number of interesting findings on the basis of which it can be confirmed that despite the fact that private labels appeared in Slovakia later than it was in the case of our "neighbors" (note: first private labels appeared in Hungary in 1996 [74] and in the Czech Republic in 1991 [75], their establishment on the Slovak market was in many respects faster and more efficient.

In terms of encountering the concept of private labels, it can be said that although most respondents stated that they had already encountered the concept (73.96\% of respondents), there were also respondents who could not describe the term (despite the fact that almost $72 \%$ of respondents from Hungary and $99 \%$ of respondents from Slovakia reported that they know the term, up to 63 respondents from Hungary the concept could not clarify or give concrete examples and 7 respondents from Slovakia were not sure); or they were able to describe it even though they stated that they did not know this term and they could not judge. The most positive findings were recorded in the case of respondents from Slovakia and the Czech Republic, as up to $84.87 \%$ of respondents from Slovakia, $78.42 \%$ of respondents from Hungary and up to $87.41 \%$ of respondents from the Czech Republic knew the term whether verbally or give specific examples. This finding is surprising, as on the one hand, as according to PLMA data from 2019, the share of private label chain purchases in household expenditure was the largest (for the surveyed V4 countries) in Hungary (34\%), then in Slovakia (32\%), followed by Poland $(31 \%)$ and then in the Czech Republic (30\%) [45], so it was expected that the term will be known mainly to respondents from Hungary, Slovakia and then the Czech Republic. But on the other hand, when respondents do not know this term it does not necessarily mean that they do not buy the private label products.

Regarding the evaluation of questions concerning the purchase of private labels, the preferences or the purchase of specific types and categories of private labels shows many interesting and positive findings; out of a total of 3038 respondents, up to $85.02 \%$ purchase private label products, $34 \%$ of respondents purchase them regularly and $53.69 \%$ of respondents purchase them sporadically); up to $32.49 \%$ prefer to purchase them over traditional brands; and up to $42.63 \%$ purchase mainly classic private labels, while up to $29.26 \%$ purchase mainly private labels identical with the retail chain name.

If we look at the evaluation of the questions from the point of view of each surveyed country, we would notice that there are no fundamental differences between the answers (Figure 1), so it cannot be said that respondents from one country would buy or prefer private labels more than respondents from another country, despite the fact that private labels were introduced to the Hungarian and Czech 
markets sooner than to the Slovak market and the fact that, according to results of research agencies, private labels from the V4 countries point of view are purchased mainly in Hungary and Slovakia. According the results of our research, there are no significant differences in respondents' answers from the point of view of the surveyed V4 countries.
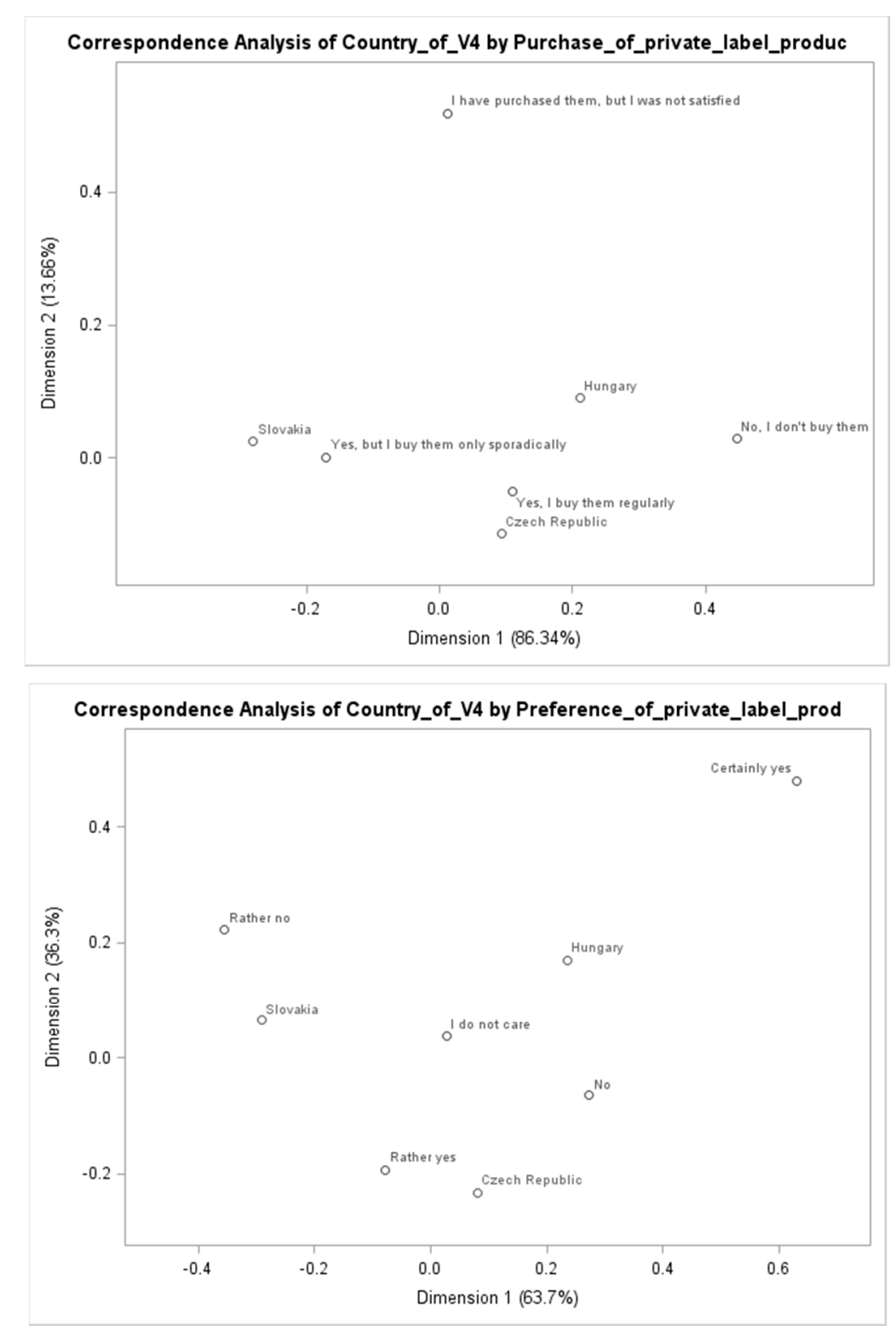

Figure 1. Correspondence analysis of V4 countries by purchase the private label products. Correspondence analysis output when evaluating the dependence between respondents' choice of answers depending on country of residence within V4 countries; Source: results of the research.

However, regarding the evaluation of the question relating to specific product categories in which respondents purchase the private labels, respectively in which private labels explicitly favor traditional brands, there are already some differences in responses. In general, respondents purchase and prefer private labels mainly in the milk and dairy products, as well as mineral waters, lemonades and juices (Tables 2 and 3). 
Table 2. The most frequently purchased private label product categories; source: questionnaire survey results, XL Stat.

\begin{tabular}{|c|c|c|c|c|c|c|c|c|}
\hline Friedman's Test & & & & & & & & \\
\hline $\mathrm{Q}$ (measured value) & 746.316 & & & & & & & \\
\hline $\mathrm{Q}$ (critical value) & 16.919 & & & & & & & \\
\hline DF & 9 & & & & & & & \\
\hline$p$-value (bilateral) & $<0.0001$ & & & & & & & \\
\hline Alpha & 0.05 & & & & & & & \\
\hline Sample & Frequency & Total & $\varnothing$ & & & Groups & & \\
\hline [Milk and dairy products] & 3.038 & $11,469.500$ & 3.775 & A & & & & \\
\hline [Mineral waters, lemonades, juices] & 3.038 & $13,583.500$ & 4.471 & & $\mathrm{~B}$ & & & \\
\hline [Salty snacks] & 3.038 & $14,294.000$ & 4.705 & & $\mathrm{~B}$ & & & \\
\hline [Confectionery] & 3.038 & $14,857.500$ & 4.891 & & $\mathrm{~B}$ & & & \\
\hline [Frozen semi-finished products] & 3.038 & $16,856.000$ & 5.548 & & & $\mathrm{C}$ & & \\
\hline [Delicatessen, Canned food] & 3.038 & $17,118.500$ & 5.635 & & & $\mathrm{C}$ & & \\
\hline [Coffee, Tea] & 3.038 & $18,189.500$ & 5.987 & & & $\mathrm{C}$ & $\mathrm{D}$ & \\
\hline [Meat and Fish] & 3.038 & $18,777.500$ & 6.181 & & & $\mathrm{C}$ & $\mathrm{D}$ & \\
\hline [Ready meals] & 3.038 & $19,999.000$ & 6.583 & & & & $\mathrm{D}$ & $\mathrm{E}$ \\
\hline [Alcoholic beverages] & 3.038 & $21,945.000$ & 7.224 & & & & & $\mathrm{E}$ \\
\hline
\end{tabular}

Table 3. A product category where the private label is preferred over the traditional brand; source: questionnaire survey results, XL Stat.

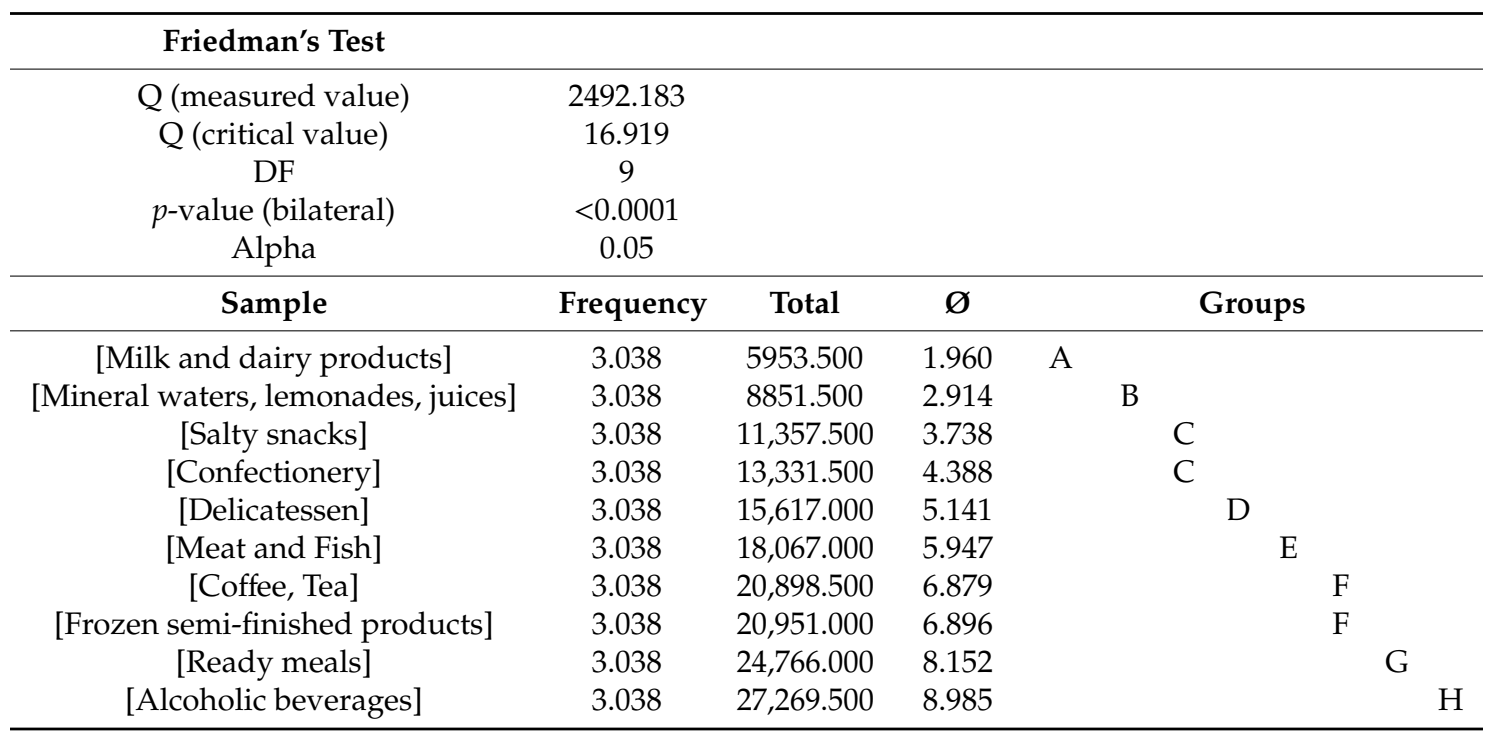

The aforementioned differences in respondents' responses were also found in the XL Stat program using the Kruskal-Wallis test, which suggests that there are statistically significant differences between respondents' responses from individual surveyed countries when private labels are preferred over traditional brands for product categories meat and fish, milk and dairy products and ready meals, and in terms of the specific product categories in which private labels are purchased, these differences are significant for the meat and fish, delicatessen and canned product categories as well as ready meals. On the basis of the above mentioned it can be concluded that private labels are purchased mainly in the product categories meat and fish, delicatessen, canned food and ready meals, mainly by respondents from Slovakia and the Czech Republic; in the case of their preference or preference to traditional brands, this can be said for the categories of meat and fish, milk and dairy products and ready meals, especially among respondents from the Czech Republic and Slovakia. The above results partly correspond with the findings of the Nielsen agency in 2017 [76], when it was found that Czechs under a private label in the food category primarily prefer milk and dairy products (average $31.25 \%$ ), 
cooking oils (36\%), canned food (average $34 \%$ ), salty snacks (29\%), packaged bread $(27 \%)$ and even sweet packaged pastries $(25 \%)$ and juices (22\%).

To determine whether there are statistically significant differences between respondents' answers to questions about purchased and preferred private label product categories in terms of their selected characteristics and whether there are differences between the most commonly purchased private label categories in terms of gender, economic activity or respondents' education and differences between product categories where private labels are preferred over traditional brands and gender, as well as their economic activity or education, the mentioned variants of dependency were also evaluated in the XL Stat program, based on the results, suggesting that differences in responses were observed for product categories:

- milk and dairy products as well as salty snacks: the private label product of these categories are purchased more by women than by men,

- meat and fish, milk and dairy products, confectionery and frozen semifinished products are purchased by respondents from category "other education". Delicatessen, coffee and tea, are mostly purchased by respondents with a higher education, and ready meals are mostly purchased by respondents with secondary education without A level and respondents with other education,

- confectionery is bought more by women on maternity leave than by other economic categories of respondents,

- meat and fish as well as alcoholic beverages are purchased more by respondents with a net monthly household income of up to EUR 500. Delicatessen are purchased more by respondents with net monthly household income ranging from EUR 801 to EUR 1100 from EUR 1101 to EUR 1500 and above EUR 1501 than respondents with other ranges of net monthly household income, or product categories:

- milk and dairy products and salty snacks: private label products are preferred over traditional brand products by women rather than by men,

- meat and fish, where respondents with a different level of education prefer the given category of private label products rather than traditional label products (usually respondents from category "University education II. Grade"),

- milk and dairy products, confectionery and salty snacks, where private label products are preferred over the traditional ones mostly by women on maternity leave than other economic categories of respondents.

The evaluation of these two questions was also examined from the perspective of specific V4 countries. In this case we also focused on whether there are statistically significant dependencies between respondents' choice of answer to a given question and their characteristics, i.e., gender, education, economic activity, etc. Based on the results of Kruskal-Wallis test, it can be said that in the case of Slovak respondents there were statistically significant differences in the product categories of confectionery and salty snacks, where private label products are preferred by respondents with a net monthly household income ranging from EUR 801 to EUR 1100 more than respondents with different ranges of net monthly family income. Milk and dairy products and mineral waters, lemonades and juices are purchased more by women rather than men.

For respondents from Hungary, the differences were found in the product categories of frozen semi-finished products and meat and fish, where the private label products are preferred by women with secondary education with A level as well as without A level. In the product categories milk and dairy products, mineral waters, lemonades and juices, frozen semifinished products, coffee and tea and meat and fish: the private label product categories are purchased more by male respondents with university and secondary education with A level or respondents with net monthly household income of up to EUR 500 .

In the case of respondents from the Czech Republic, the product categories of milk and dairy products, salty snacks, confectionery and coffee and tea is the preference for private label products by 
male respondents, respondents with university education I. grade or higher education, respondents on maternity leave, self-employed, employed and students. In the case of the product categories milk and dairy products, confectionery and salty snacks, these are purchased more by men, respondents with other education and retired or employed respondents.

As [66] states, despite the fact that the consumer usually makes the purchasing decision before entering the store, up to 7 out of 10 purchasing decisions are made directly in the shop-in $47 \%$ of cases consumer behavior changes due to various factors in store, e.g., due to communication, affordability, news, special offer, product placement, private label products offerings and eventually other factors. For this reason, we included to our research questions concerning the factors leading to or discouraging from purchase the private label products as well as the possibility of reaching the potential customers. Based on the evaluation of these questions, it can be concluded that while the most important factors leading to purchase the private label products can be considered quality and good past experience (Table 4) and not the price as it has been found until recently by [77] or by [78], the most important factor discouraging to purchase the private label products is their low quality (Table 5).

Table 4. Factors leading to purchase the private label products; source: questionnaire survey results, XL Stat.

\begin{tabular}{|c|c|c|c|c|c|c|}
\hline Friedman's Test: & & & & & & \\
\hline Q (measured value) & 101.934 & & & & & \\
\hline $\mathrm{Q}$ (critical value) & 9.488 & & & & & \\
\hline $\mathrm{DF}$ & 4 & & & & & \\
\hline$p$-value (bilateral) & $<0.0001$ & & & & & \\
\hline Alpha & 0.05 & & & & & \\
\hline Sample & Frequency & Total & $\varnothing$ & & Groups & \\
\hline [Quality] & 3.038 & 8168.500 & 2.688 & A & & \\
\hline [Good previous experience] & 3.038 & 8365.000 & 2.753 & A & & \\
\hline [The price] & 3.038 & 9341.500 & 3.075 & & B & \\
\hline [Combination of reasonable price and quality] & 3.038 & 9429.000 & 3.104 & & $\mathrm{~B}$ & $\mathrm{C}$ \\
\hline [Recommendations from friends] & 3.038 & $10,269.000$ & 3.380 & & & $\mathrm{C}$ \\
\hline
\end{tabular}

Table 5. Factors discouraging from purchase the private label products; source: questionnaire survey results, XL Stat.

\begin{tabular}{cccccc}
\hline Friedman's Test: & & & & \\
\hline $\mathrm{Q}$ (measured value) & 41.613 & & & \\
$\mathrm{Q}$ (critical value) & 14.067 & & & \\
DF & 7 & & & & \\
$p$-value (bilateral) & $<0.0001$ & & & & \\
Alpha & 0.05 & & & & \\
\hline Sample & Frequency & Total & $\varnothing$ & Groups \\
\hline [Low Quality] & 3.038 & $12,663.000$ & 4.168 & $\mathrm{~A}$ & \\
[Lack of information about producer] & 3.038 & $13,086.500$ & 4.308 & $\mathrm{~A}$ & $\mathrm{~B}$ \\
[Taste] & 3.038 & $13,293.000$ & 4.376 & $\mathrm{~A}$ & $\mathrm{~B}$ \\
[Freshness] & 3.038 & $13,622.000$ & 4.484 & $\mathrm{~A}$ & $\mathrm{~B}$ \\
[Country of origin] & 3.038 & $13,681.500$ & 4.503 & $\mathrm{~A}$ & $\mathrm{~B}$ \\
[High price] & 3.038 & $14,126.000$ & 4.650 & $\mathrm{~A}$ & $\mathrm{~B}$ \\
[Texture] & 3.038 & $14,350.000$ & 4.724 & & $\mathrm{~B}$ \\
[Unattractive packaging] & 3.038 & $14,546.000$ & 4.788 & & $\mathrm{~B}$ \\
\hline
\end{tabular}

Following the evaluation of the above questions-which factors affect respondents to purchase the private label products and questions about the dependence between respondents' choice of answers-we discuss as to whether there are statistically significant dependencies between the choice of respondents' response to the question concerning the factors leading to purchase the private labels, 
i.e., the factors discouraging from purchase the private labels and their gender, education or whether there are statistically significant differences between respondents' answers from the perspective of the surveyed V4 countries, i.e., whether respondents from Slovakia, Hungary and the Czech Republic are influenced by various factors in the purchase the private labels. The evaluation of the given dependencies shows that, while the total number of 3038 respondents, most of the respondents would be influenced by the most interesting form of promotion, recommendation and tasting $(30.88 \%, 19.59 \%$ and $17.05 \%$ of respondents) to purchase the private label products. In the case of respondents from Slovakia, it would be an especially interesting form of promotion, tastings and free samples $(37.50 \%$, $17.76 \%$ and $15.13 \%$ of respondents), for respondents from Hungary it would be recommendations, tastings and a more interesting form of promotion $(24.46 \%, 20.14 \%$ and $20.14 \%$ of respondents) while in case of respondents from the Czech Republic it would be a more interesting form of promotion, recommendations and classical advertising (34.27\%, $20.98 \%$ and $15.38 \%$ of respondents). On the basis of above mentioned, as well as the results presented in Table 6, it can be said that there is a statistically significant correlation between the factors influencing and leading respondents to purchase the private labels products and country of residence within V4 countries.

Table 6. Dependencies between the factors influencing and leading respondents to purchase the private label products and country of residence within V4 countries; source: questionnaire survey results, SAS Enterprise Guide 7.1.

\begin{tabular}{cccc}
\hline Statistical Test/Coefficient & Value & DF & Probability \\
\hline Chi Square Test & 12 & 23.2403 & 0.0258 \\
Probability ratio of Chi-square test & 12 & 24.1812 & 0.0192 \\
Mantel-Haenszel Chi-square test & 1 & 0.0329 & 0.8561 \\
Phi coefficient & & 0.2314 & \\
Contingency coefficient & & 0.2254 & \\
Cramer's V contingency coefficient & & 0.1636 & \\
\hline
\end{tabular}

The above-formulated dependencies were again evaluated in the XL Stat program by using Kruskal-Wallis test, which suggests that, within the factors leading to purchase the private label products were found the differences in these variables:

- quality, combination of reasonable price and quality, good previous experience and recommendations from friends where it can be said that these factors are more relevant to respondents from Slovakia and the Czech Republic,

- price, quality, combination of reasonable price and quality, good previous experience and recommendations from friends are followed by female respondents more than male respondents,

- quality, combination of reasonable price and quality, good previous experience and recommendations from friends, where it can be said that these factors are leading to the purchase of private label products by respondents with a higher education (university education I. grade and II. grade) more than by respondents with lower levels of education.

- quality and recommendations from friends are more relevant to respondents on maternity leave, employed and retired respondents than to other economic categories of respondents,

- $\quad$ price is crucial for respondents with a net monthly family income of up to EUR 500.

In a case of discouraging factors from purchase the private label products, the variables are as follows:

- high price, low quality, taste, consistency, freshness, country of origin and lack of information about producer discouraging from purchasing the private label products by respondents from Slovakia rather than from Hungary and the Czech Republic,

- high price and country of origin, which are crucial for respondents with a secondary education with A level, low quality, which mainly discourage respondents with different levels of education, 
taste and consistency discourage respondents with secondary education with A level, rather than respondents with higher levels of education. Freshness discourages respondents with lower levels of education (primary and secondary education) rather than respondents with higher levels of education, price is once again crucial for respondents with a net monthly household income of up to EUR500.

When evaluating the given dependencies from the perspective of the surveyed V4 countries, we used a Kruskal-Wallis test to determine whether there were statistically significant differences between respondents' answers.

The results of the test show that, while for Slovak respondents, differences were found for the combination of reasonable price and quality leading to purchase the private label products rather than men), recommendations of friends (leading to purchase of private label products rather by women than men) and high price (which discourages the purchase of private labels from respondents with a secondary education with a school-leaving certificate, rather than respondents with other levels of education).

In the case of respondents from Hungary it was quality, combination of reasonable price and quality that were significant more for men than women and poor quality (which discourages self-employed respondents rather than employed ones) and, for Czech respondents, price, combination of reasonable price and quality and good previous experience (more relevant to men than for women) and consistency discouraging purchasing the private label products by respondents with other levels of education.

As the present, customers are more sensitive in terms of perceived quality, longer durability and special product characteristics [49], and few researches have proven that there are differences in buying behavior of consumers in relation to the brand perception (e.g., $[55,56,79,80])$. In the questionnaire survey we also focused on the quality level of private label products, more precisely, the perception of the quality of private labels and comparability of the quality of private label products with products of traditional brands from the perspective of the surveyed V4 countries. In this case, it can be stated that the results of our questionnaire survey proved good and comparable quality with very similar results, as most respondents, $(77.88 \%)$ said the private labels evoke adequate quality at a reasonable price (78.29\% of respondents from Slovakia, $73.38 \%$ of respondents from Hungary and $81.82 \%$ of respondents from the Czech Republic), exactly half of the respondents thought that private label products are characterized by good, respective of adequate quality (73.03\% of respondents from Slovakia, $2.88 \%$ of respondents from Hungary and $71.33 \%$ of respondents from the Czech Republic), while $52.76 \%$ of respondents think that the quality of private label products is more comparable to the quality of traditional brand products, up to $21.89 \%$ of respondents are convinced of this $(19.74 \%$ of respondents from Slovakia, $23.02 \%$ of respondents from Hungary and $23.08 \%$ of respondents from the Czech Republic).

As indicated above, minor differences in respondents' responses can be seen when evaluating the question concerning the quality of private label products, while most respondents from Slovakia and the Czech Republic think that private label products are good, respective of adequate quality, while the majority of respondents from Hungary stated that this quality was rather lower $(64.03 \%$ of respondents). The above finding is quite surprising, as the results by Nielsen research, carried out in 2015, showed that the quality of private labels in Hungary had improved over the last few years, as up to 7 out of 10 customers reported [81]. However, although quality has improved, customers are still observing the reserves that could be improved.

In connection with the finding that respondents from Hungary perceive the quality of private labels rather than lower, we were also interested in whether there is a statistically significant relationship between the perception of quality of private label products and the characteristics of respondents, between the perception of the quality of private label products and their purchase, respectively. These dependencies were identified in SAS Enterprise Guide 7.1 by using association tests, which show that statistically significant dependencies exist only when evaluating the quality of private label products and their purchase ( $p$-value at significance level $\lambda$ equals 0.0324 , which can be interpreted as a 
statistically significant dependence). However, this dependence can only be perceived as a mean, since the value of Phi coefficient was equal to 0.3636 , the value of the Crammer's V contingency coefficient was equal to 0.2099 which can be interpreted as the mean, and weak dependence (Table 7).

Table 7. Dependence between selected variables; source: questionnaire survey results, SAS Enterprise Guide 7.1; Note: PLP—private label products.

\begin{tabular}{ccccc}
\hline Association & $\begin{array}{c}\text { Chi-Square } \\
\text { Test Value }\end{array}$ & Probability & Phi Coefficient & $\begin{array}{c}\text { Cramer's V } \\
\text { Contingency } \\
\text { Coefficient }\end{array}$ \\
\hline $\begin{array}{c}\text { Assessment of PLP quality } \\
\text { and respondent qender } \\
\text { Evaluation of the quality of } \\
\text { PLP and respondent education } \\
\text { Assessment of the quality of } \\
\quad \text { PLP and respondent } \\
\quad \text { eco activity }\end{array}$ & 6.2852 & 0.0985 & 0.2134 & 0.2134 \\
$\begin{array}{c}\text { Assessment of PPL quality } \\
\text { and net monthly } \\
\text { household income }\end{array}$ & 17.1789 & 0.1759 & 0.2548 & 0.1802 \\
$\begin{array}{c}\text { Evaluation of PLP quality and } \\
\text { purchasing of PLP }\end{array}$ & 18.2460 & 0.0842 & 0.4082 & 0.2357 \\
\hline
\end{tabular}

The results of association tests can be further interpreted (despite the fact that that respondents from Hungary mostly reported that the quality of private label products is lower) so that they purchase, and in many cases even mentioned, that in terms of comparability of quality with traditional brand products, the quality of private label products is comparable.

Regarding the recommendation to purchase the private label products, i.e., what the respondents would change if they had the opportunity, most respondents would recommend the purchase of private label products, as $30.88 \%$ of respondents answered certainly yes and $47.93 \%$ of respondents said yes. Additionally, if they had the chance to change something, it would be primarily knowledge of private labels ( $30.41 \%$ of respondents) and the quality that they would like to increase ( $15.90 \%$ of respondents).

If we look at the surveyed V4 countries from the point of view of evaluating these questions, we would find that while there are no fundamental differences between the respondents' answers when recommending private label products, in the question what they would like to change in private label products, differences have already been observed. While respondents from Slovakia and the Czech Republic would increase the awareness of private labels, for example in the form of advertising, respondents from Hungary would like to increase the quality in particular, but this is not so surprising as the respondents from Hungary reported lower quality of the private label products in the question regarding the perception of the quality of private label products. This dependence was confirmed by the output of SAS Enterprise Guide 7.1, based on the results, which showed that between the respondents' choice of answering a question about what would change on private labels and the country of residence is a statistically significant dependence ( $p$-value it was less than 0.0001 at the significance level $\lambda$, which can be interpreted as a statistically significant dependence). However, this dependence is more weak than moderate (since the value of Phi coefficient and Crammer's V contingency coefficient were 0.2914 and 0.2060, respectively, which can be interpreted as weak dependence) (Table 8). 
Table 8. Dependence between what respondents would change on private labels and their origin within V4 countries; source: questionnaire survey results, SAS Enterprise Guide 7.1.

\begin{tabular}{cccc}
\hline Statistical Test/Coefficient & Value & DF & Probability \\
\hline Chi Square Test & 10 & 36.8436 & $<0.0001$ \\
Probability ratio of Chi-square test & 10 & 38.2003 & $<0.0001$ \\
Mantel-Haenszel Chi-square test & 1 & 0.0463 & 0.8297 \\
Phi coefficient & & 0.2914 & \\
Contingency coefficient & & 0.2797 & \\
Cramer's V contingency coefficient & & 0.2060 & \\
\hline
\end{tabular}

\section{Conclusions}

As [82] also point out, building customer loyalty is a continuous long-distance run without a goal, but maintaining a good pace is likely that in situations where a customer will have to decide whether to buy a traditional brand product or service, which means essentially nothing to him excluding the packaging or logo, or whether he chooses a private label product or service that will provide him with a similar product or service, but at a lower price. A private label will win this customer and he will become its loyal user. Private label is not only an alternative to purchase and therefore a source of benefits for the customer, but also a source of competitive advantage for retail chains, as the company/retail chain's competitiveness is linked not only to economic outcomes [83], but also the good name and perceived image by its customers.

The aim of the submitted paper was not only to bring the issue of private labels to the general public, but also to identify and analyze possible differences between the knowledge, perception and preference of private labels by selected groups of respondents, i.e., respondents under 25 years of age, and at the same time inhabitants of selected V4 countries-Slovakia, Hungary and the Czech Republic. The results of our questionnaire survey showed many interesting findings on the basis of which it can be confirmed that despite the fact that private labels appeared in Slovakia later than in the case of Hungary and the Czech Republic, their establishment on the Slovak market was in many respects faster and more efficient.

The key findings of our questionnaire survey can be concluded as follows:

- despite the fact that the majority of respondents declared that they know the concept of private labels (almost $74 \%$ of respondents),

- most respondents buy private label products (85.02\%); more than $32 \%$ of respondents explicitly favor them over traditional brands in their purchases;

- quality and good previous experience, as well as combination of reasonable price and quality, are clearly the most important factors leading to purchase the private labels;

- the most important factors discouraging purchasing the private label products is their expected low quality;

- regarding the quality level of private labels, most respondents stated that private labels evoke adequate quality at reasonable price ( $78 \%$ of respondents from Slovakia, $73 \%$ of respondents from Hungary and $82 \%$ of respondents from the Czech Republic), exactly half of the respondents think that private label products are good or adequate quality (73\% of respondents from Slovakia, $3 \%$ of respondents from Hungary and $71 \%$ of respondents from the Czech Republic), while almost 53\% of respondents think that the quality of private label products is more comparable to traditional brand products,

- in terms of satisfaction with private labels, their recommendations and what would affect respondents to purchase the private label products, it can be said that most respondents would recommend purchasing the private labels to others; most respondents are satisfied with them, but if they had the opportunity to change something, it would be their quality, packaging and knowledge about them, 
- regarding the question what would affect them for their purchase, answers were mostly the classic forms of marketing communication, such as recommendations from friends, more interesting form of promotion and tasting. This seems to us quite surprising, because currently it is said that consumers are active creators of communication content and not just passive receivers of messages and that social media are used more often due to the fact that they have boosted marketing practices, such as advertising and promotion, their unmatched features and enormous popularity $[84,85]$. However, as our research suggests, private labels are an exception. This statement was also confirmed by the analysis of the answers of respondents from specific V4 countries, although some slight differences in answers can be observed, whereas in the case of respondents from Slovakia they would be influenced by the more interesting form of promotion, tasting and free samples (38\%, $18 \%$ and $15 \%$ of respondents), in the case of respondents from Hungary, it would be recommendations from friends, tastings and more interesting form of promotion $(25 \%, 20 \%$ and $20 \%$ of respondents) and in the case of Czech respondents it would be more interesting form of promotion, recommendations from friends and classic forms of advertising $(34 \%, 21 \%$ and $15 \%$ of respondents); however, these differences are not so great and it is still true that traditional forms of marketing communication prevail rather than modern forms.

Retail chains offering their products under private labels responsibility can benefit from presented findings of our research as these may represent the key factors in the success in all surveyed countries-Slovakia, Hungary and the Czech Republic. There has not been any other similar studies published yet. Therefore, it could be a great base for managerial decision making regarding the private labels in retail chains, especially in increasing loyalty of their customers under 25 years of age. This is a specific group of customers as their shopping behavior is continuously evolving. Thus, the retail chains have to continuously adapt to meet the expectations of customers under 25 years and choose the best marketing decisions to attract them.

Author Contributions: Conceptualization, I.K., Z.K., M.D. (Milan Džupina), L'.K. and M.D. (Marek Dvořák); methodology, I.K., Z.K. and M.D. (Milan Džupina); software, I.K., Z.K. and M.D. (Milan Džupina); validation, I.K., Z.K. and M.D. (Milan Džupina); formal analysis, I.K., Z.K., M.D. (Milan Džupina), L'.K. and M.D. (Marek Dvořák); investigation, I.K., Z.K., M.D. (Milan Džupina), L'.K. and M.D. (Marek Dvořák); resources, I.K., Z.K., M.D. (Milan Džupina), L'.K. and M.D. (Marek Dvořák); data curation, I.K., Z.K. and M.D. (Milan Džupina); writing-original draft preparation, I.K., Z.K., M.D. (Milan Džupina), L'.K. and M.D. (Marek Dvořák); writing-review and editing, I.K., Z.K., M.D. (Milan Džupina), L'.K. and M.D. (Marek Dvořák); visualization, I.K., Z.K., M.D. (Milan Džupina), L'.K. and M.D. (Marek Dvořák); supervision, I.K. and Z.K.; project administration, I.K. and Z.K.; funding acquisition, I.K., Z.K., M.D. (Milan Džupina), L'.K. and M.D. (Marek Dvořák). All authors have read and agreed to the published version of the manuscript.

Funding: This research received no external funding.

Conflicts of Interest: The authors declare no conflict of interest.

\section{References}

1. Šrédl, K.; Soukup, A.; Severová, L. Models of Consumer's Choice. E+M Ekon. Manag. 2013, 2, 4-9.

2. Lorincová, S.; Hitka, M.; Štarchoň, P.; Stachová, K. Strategic Instrument for Sustainability of Human Resource Management in Small and Medium-Sized Enterprises Using Management Data. Sustainability 2018, $10,3687$. [CrossRef]

3. Smutka, L.; Svatoš, M.; Tomšík, K.; Sergienko, O.I. Foreign trade in agricultural products in the Czech Republic. Agric. Econ. 2016, 62, 9-25. [CrossRef]

4. Maitah, M.; Smutka, L. Economic analysis of milk production and consumption in the Middle East and North Africa. Acta Univ. Agric. Silvic. Mendel. Brun. 2012, 60, 245-254. [CrossRef]

5. Benesova, I.; Maitah, M.; Smutka, L.; Tomsik, K.; Ishchukova, N. Perspectives of the russian agricultural exports in terms of comparative advantage. Agric. Econ. 2017, 63, 318-330. [CrossRef]

6. Špička, J.; Smutka, L. The Technical Efficiency of Specialised Milk Farms: A Regional View. Sci. World J. 2014, 2014, 1-13. [CrossRef] [PubMed] 
7. Severová, L.; Bendl, S. Cartels and its behaviour on food markets. Agric. Econ. (Zemědělská ekonomika) 2013, 59, 81-89. [CrossRef]

8. Lee, W.-C.; Wang, S.-S. Misallocations and policy constraints on mergers in the modern manufacturing sector. J. Macroecon. 2017, 52, 268-286. [CrossRef]

9. Eccless, R.G.; Newquist, S.C.; Schatz, R. Reputation and its Risks. Harv. Bus. Rev. 2007, 85, 104. Available online: https://hbr.org/2007/02/reputation-and-its-risks (accessed on 15 August 2020).

10. Wood, L. Brands and brand equity: Definition and management. Manag. Decis. 2000, 38, 662-669. [CrossRef]

11. Semeijn, J.; Van Riel, A.C.; Ambrosini, A. Consumer evaluations of store brands: Effects of store image and product attributes. J. Retail. Consum. Serv. 2004, 11, 247-258. [CrossRef]

12. European Commission. Study on Economic Value of EU Quality Schemes Geographical Indications (GI) and Traditional Specialities Guaranteed (TSG); European Commission, Directorate General for Agriculture and Rural Development: Brussels, Belgium, 2019. Available online: https:/op.europa.eu/en/publication-detail/-/ publication/a7281794-7ebe-11ea-aea8-01aa75ed71a1/language-en/format-PDF/source-125033244 (accessed on 25 April 2020).

13. Nielsen. The Rise and Rise Aain of Private Label. 2018. Available online: https: //www.nielsen.com/content/dam/nielsenglobal/ru/docs/2018.02\%20-\%20Global\%20-\%20The\%20Rise\% 20and\%20Rise\%20Again\%20of\%20Private\%20Label.pdf (accessed on 29 August 2020).

14. Herstein, R.; Gamliel, E. An Investigation of Private Branding as a Global Phenomenon. J. Euromarketing 2004, 13, 59-77. [CrossRef]

15. Smith, R.K.; Bashaw, R.E. Using Information Processing To Build A Private Label Brand In Big Emerging Markets. Int. Bus. Econ. Res. J. IBER 2011, 8, 27-42. [CrossRef]

16. Kakkos, N.; Trivellas, P.; Sdrolias, L. Identifying Drivers of Purchase Intention for Private Label Brands. Preliminary Evidence from Greek Consumers. Procedia Soc. Behav. Sci. 2015, 175, 522-528. [CrossRef]

17. Khodjamirian, S. The OFT's Approach to Attributing Merging Parties' Private Labels to Retailers for its Competitive Assessment: An Economic Comment Based on Bargaining Theory. Glob. Antitrust Rev. 2012, 181-188.

18. Baltas, G. Determinants of store brand choice: A behavioral analysis. J. Prod. Brand Manag. 1997, 6, 315-324. [CrossRef]

19. Lincoln, K.; Thomassen, L. Private Label: Turning the Retail. Brand Heart into Your Biggest Opportunity; Kogan Page: London, UK, 2008; p. 320.

20. Bárta, V.; Pátík, L.; Postler, M. Retail. Marketing; Management Press, s. r. o.: Prague, Czech Republic, 2009; p. 326.

21. Halada, J. Marketingová Komunikace a Public Relations: Výklad Pojmů a Teorie; Univrzita Karlova v Praze: Prague, Czech Republic, 2015; p. 120.

22. Frešáčik. Tajomstvo privátnych značiek. Available online: http://ww.freshobchod.sk/katalogy/fresacik.pdf (accessed on 31 August 2020).

23. Mach, J.; Dvořák, M.; Hošková, P. EU Milk and Dairy Market Changes and Impact of Globalisation Trends. In Globalization and Its Socio-Economic Consequences (Part. III.-Economic Progress in Post-Soviet Countries), Proceedings of the 18th International Scientific Conference, Rajecke Teplice, Slovakia, 10 October 2018; ZU-University of Zilina: Zilina, Slovakia, 2018; pp. 1204-1212.

24. Balcarová, T.; Pokorná, J.; Pilař, L. The Influence of Children on the Parents Buying Behavior: Food Purchase in the Czech Republic. Agris On-line Pap. Econ. Inf. 2014, 6, 11-19. [CrossRef]

25. Collins-Dodd, C.; Lindley, T. Store brands and retail differentiation: The influence of store image and store brand attitude on store own brand perceptions. J. Retail. Consum. Serv. 2003, 10, 345-352. [CrossRef]

26. Corstjens, M.; Lal, R. Building Store Loyalty through Store Brands. J. Mark. Res. 2000, 37, 281-291. [CrossRef]

27. Richardson, P.S.; Jain, A.K.; Dick, A. Household store brand proneness: A framework. J. Retail. 1996, 72, 159-185. [CrossRef]

28. Kotler, P.; Keller, K.L. Marketing Management, 12th ed.; Grada Publishing, a.s.: Prague, Czech Republic, 2007; p. 792.

29. Tvrdoň, O.; Přibyl, M. Význam maloobchodních značek pro zvýšení prodeje zboží. Acta Univ. Agric. Silvic. Mendel. Brun. 2004, 52, 145-156. [CrossRef]

30. Putsis, W.P.; Dhar, R. An empirical analysis of the determinants of category expenditure. J. Bus. Res. 2001, 52, 277-291. [CrossRef] 
31. Blattberg, R.C.; Wisniewski, K.J. Price-Induced Patterns of Competition. Mark. Sci. 1989, 8, $291-309$. [CrossRef]

32. Allenby, G.M.; Rossi, P.E. Quality Perceptions and Asymmetric Switching Between Brands. Mark. Sci. 1991, 10, 185-204. [CrossRef]

33. Hsiao, S.-H.; Wang, Y.-Y.; Wang, T.; Kao, T.-W.D. How social media shapes the fashion industry: The spillover effects between private labels and national brands. Ind. Mark. Manag. 2020, 86, 40-51. [CrossRef]

34. Lin, H.H.; Li, H.T.; Wang, Y.S.; Tseng, T.H.; Kao, Y.L.; Wu, M.Y. Predicting Customer Lifetime Value for Hypermarket Private Label Products. J. Bus. Econ. Manag. 2017, 18, 619-635. [CrossRef]

35. Aptea.com. Our History. 2012. Available online: http://aptea.com/our-company/our-history (accessed on 3 September 2020).

36. Vilčeková, L.; Sabo, M. Nákupné správanie slovenských spotrebitel’ov naprieč vybranými demografickými ukazovatel'mi. Trendy v Podnikaní 2014, 4, 66-72.

37. Gielens, K.; Steenkamp, J.-B.E. Branding in the era of digital (dis)intermediation. Int. J. Res. Mark. 2019, 36, 367-384. [CrossRef]

38. Von Koeller, E.; Dawe, P.; Pittman, A. As Grocery Goes Digital How Should CPG Supply Chains Adapt? The Boston Consulting Group Inc.: Boston, MA, USA, 2017.

39. Breugelmans, E.; Gijsbrechts, E.; Campo, K. Product unavailability. In Handbook of Research on Retailing; Gielens, K., Gijsbrechts, E., Eds.; Edward Elgar: Cheltenham, UK, 2018; pp. 202-219.

40. Verhoef, P.C.; Sloot, L.M. Out-of-stock: Reactions, antecedents, management solutions, and a future perspective. In Retailing in the 21st Century: Current and Future Trends; Krafft, M., Mantrala, M., Eds.; Springer: Berlin/Heidelberg, Germany, 2009; pp. 239-253.

41. Tisková Konference Svazu Obchodu a Cestovního Ruchu a GfK. 2018. Available online: http://www.socr.cz/ file/4460/Tiskova_konference_SOCR_GfK_prezentace.pdf (accessed on 3 September 2020).

42. Horáček, F. Čechy Pŕitahují Značky Obchodních Řetězců. Nejvíc Jogurty a Mléko. 2019. Available online: https://www.idnes.cz/ekonomika/domaci/privatni-znacky-obchodni-retezce-rust-gfk.A190419_ 180421_ekonomika_fih (accessed on 3 September 2020).

43. PLMA. Industry News. Private Label Today. 2018. Available online: https:/www.plmainternational.com/ industry-news/private-label-today (accessed on 29 August 2020).

44. PLMA. Private Label Gains across Europe, Climbing to All-Time Highs in Seven Countries. 2018b. Available online: https://www.plmainternational.com/news-update (accessed on 29 August 2020).

45. Hallett, L. Private Label Continues to Grow in Europe. 2019. Available online: https://storebrands.com/ private-label-continues-grow-europe (accessed on 29 August 2020).

46. Castelló, A.M. La batalla entre marca de distribuidor (MDD) y marcade fabricante (MDF) en el terreno publicitario. Pensar la Publicidad. Revista Internacionale Investigaciones Publicitarias 2012, 6, 381-405.

47. Ruiz-Real, J.L.; Gázquez-Abad, J.; Esteban-Millat, I.; Martínez-López, F. Betting exclusively for private labels: Could it have negative consequences for retailers? Span. J. Mark. ESIC 2017, 22, 183-202. [CrossRef]

48. Higham, W. Trendológia. The Next Big Thing; EastoneBooks: Bratislava, Slovakia, 2010; p. 266.

49. Bulanda, I.; Viteková, I.; Koprda, T.; Blahová, B. Slovak consumers from generation Y and their shopping behavior on discount portals. In Proceedings of International Scientific Days 2018: Towards Productive, Sustainable and Resilient Global Agriculture and Food Systems; Wolters Kluwer: Prague, Czech Republic, 2018; pp. 275-287. [CrossRef]

50. Rogers, E.M. Diffusion of Innovations; The Free Press: New York, NY, USA, 2003; p. 576.

51. Karim, N.; Oyefolahan, I.O. Mobile phone appropriation: Exploring differences in terms of age, gender and occupation. In Proceedings of the IEEE 6th International Conference on Information Technology and Applications, Hanoi, Thailand, 15-18 December 2009.

52. Pieri, M.; Diamantinir, D. Young people, elderly and ICT. Procedia Soc. Behav. Sci. 2010, 2, $2422-2426$. [CrossRef]

53. Ansari, M.S.; Channar, Z.A.; Syed, A. Mobile phone adoption and appropriation among the young generation. Procedia Soc. Behav. Sci. 2012, 41, 265-272. [CrossRef]

54. Polakevičová, I.; Uhríková, P. Perception of the erotic theme of Dolce \& Gabbana and Calvin Klein print advertisement in terms of gender differentiation of the generation Y customer segment. Prohuman Internet Sci. J. Soc. Work Psychol. Pedagog. Soc. Policy Health Care Nurs. 2015, 7, 1-4. 
55. Šedík, P.; Horská, E.; Skowron-Grabowska, B.; Illés, C.B. Generation marketing in strategic marketing management: Case study of honey market. Pol. J. Manag. Stud. 2018, 18, 326-337. [CrossRef]

56. Šedík, P.; Kňazovická, V.; Horská, E.; Kačániová, M. Consumer sensory evaluation of honey across age cohorts in Slovakia. Potravinarstvo Slovak J. Food Sci. 2018, 12, 673-679. [CrossRef]

57. Kádeková, Z.; Košičiarová, I.; Rybanská, J. Privátne Značky Ako Alternatíva Nákupu; Verbum: Prague, Czech Republic, 2020; p. 311.

58. Kádeková, Z.; Košičiarová, I.; Vavřečka, V.; Džupina, M. The impact of packaging on consumer behavior in the private label market-The case of Slovak consumers under 25 years of age. Innov. Mark. 2020, 16, 62-73. [CrossRef]

59. Košičiarová, I.; Kádeková, Z. The consumer behaviour of young Slovak consumers (under the age of 25) in the private label market. Mark. Sci. Inspir. 2020, 15, 37-48.

60. Košičiarová, I.; Kádeková, Z.; Kubicová, L'.; Rybanská, J. The consumer behavior of Slovak millennials in the segment of milk and dairy products within private labels. Potravinarstvo Slovak J. Food Sci. 2020, 14, 798-806. [CrossRef]

61. GFK. GfK Consumer Reporter 03/2018. 2018. Available online: https://www.gfk.com/fileadmin/user_upload/ country_one_pager/SK/documents/2018/181101_GfK_Newsletter_ConsumerPanel_03-2018_skfin.pdf.pdf (accessed on 29 August 2020).

62. TASR. PRIESKUM: Predaj Značkových Tovarov Si Udržal Postavenie aj v Čase Krízy. 2010. Available online: http://www.edb.sk/sk/spravy/prieskum-predaj-znackovych-tovarov-si-udrzal-postavenie-aj-v-casekrizy-a2398.html (accessed on 29 August 2020).

63. TNS. Najvýhodnejšie Nákupy Robíme v Kauflande. Hitparáda Obchodných Ret’azcov Očami Slovákov. 2012. Available online: https://medialne.etrend.sk/marketing-tlacove-spravy/najvyhodnejsie-nakupy-robime-vkauflande.html (accessed on 3 September 2020).

64. TNS. Obl'úbenost' Privátnych Značiek na Slovensku Rastie. 2015. Available online: https://www.tnsglobal.sk/informacie-pre-vas/tlacove-spravy/oblubenost-privatnych-znaciek-na-slovensku-rastie (accessed on 3 September 2020).

65. Fedorková, J. Najvýhodnejšie Nákupy Robíme v Kaufland. 2012. Available online: http://www. tns-global.sk/informacie-pre-vas/tlacove-spravy/najvyhodnejsie-nakupy-robime-v-kauflande (accessed on 3 September 2020).

66. Valášková, K. Analýza výsledkov prieskumu nákupného správania slovenských spotrebitel'ov. EMI 2014, 6, $34-45$.

67. Debdeep, D.; Singh, A. Consumer's Perpective and Retailer's Consideration Towards Purchase of Private Label Brands. Procedia Comp. Sci. 2017, 122, 587-594. [CrossRef]

68. Calvo-Porral, C.; Lévy-Mangin, J.-P. Store brands' purchase intention: Examining the role of perceived quality. Eur. Res. Manag. Bus. Econ. 2017, 23, 90-95. [CrossRef]

69. Calvo-Porral, C.; Martinet-Fernández, V.A.; Juanatey-Boga, O.; Lévy-Mangín, J.P. What matters to store Brand Equity? An approach to Spanish large retailing in a downturn context. Investigaciones Europeas de Dirección y Economía de la Empresa 2013, 19, 136-146. [CrossRef]

70. Erdil, T.S. Effects of Customer Brand Perceptions on Store Image and Purchase Intention: An Application in Apparel Clothing. Procedia Soc. Behav. Sci. 2015, 207, 196-205. [CrossRef]

71. González-Benito, Ó.; Martos-Partal, M. Role of Retailer Positioning and Product Category on the Relationship Between Store Brand Consumption and Store Loyalty. J. Retail. 2012, 88, 236-249. [CrossRef]

72. Hansen, K.; Singh, V. Research Note-Are Store-Brand Buyers Store Loyal? An Empirical Investigation. Manag. Sci. 2008, 54, 1828-1834. [CrossRef]

73. Hansen, K.; Singh, V.; Chintagunta, P.K. Understanding Store-Brand Purchase Behavior Across Categories. Mark. Sci. 2006, 25, 75-90. [CrossRef]

74. Balló, Z. Analysis of Factors Influencing Customer Behavior of Private Labels on the Hungarian Fast Moving Consumer Goods Market. Ph.D. Thesis, Szent István Egyetem Gödölő, Gödölő, Hungary, 2013.

75. Klečka, J. Development of Private Labels in the Dairy Products Sector in the Czech Republic. Int. Adv. Econ. Res. 2017, 23, 355-356. Available online: https://www.questia.com/library/journal/1G1-509015935/ development-of-private-labels-in-the-dairy-products (accessed on 15 August 2020). [CrossRef] 
76. Týra, K. Tisková Konference Svazu Obchodu a Cestovního Ruchu ČR a Výzkumné Společnosti Nielsen. 2017. Available online: http://www.socr.cz/file/4184/Tiskova_konference_SOCR_Nielsen_7_12_2017.pdf (accessed on 3 September 2020).

77. Burt, S. The strategic role of retail brands in British grocery retailing. Eur. J. Mark. 2000, 34, 875-890. [CrossRef]

78. Kumar, N.; Steenkamp, J.-B. Private Label. Strategy: How to Meet the Store Brand Challenge, 1st ed.; Harvard Business Review Press: Brighton, MA, USA, 2007; p. 270.

79. Štarchoň, P.; Ližbetinová, L.; Weberova, D. Clustering in Relation to Brand Perception: An Example Based on Czech Consmers. In Vision 2020: Innovation Management, Development Sustainability, and Competitive Economic Growth; Soliman, K.S., Ed.; International Business Information Management Association: Seville, Spain, 2016; pp. 2271-2284.

80. Světlík, J.; Bulanda, I. Adolescents Perception of the Commercial Advertising in Slovakia. In Economic and Social Development; VADEA: Buenos Aires, Argentina, 2019; pp. 201-209.

81. Progresiv. Hungary: Consumers Favour Private Label Products. 2015. Available online: https://www. magazinulprogresiv.ro/node/762 (accessed on 31 August 2020).

82. Kicová, E.; Kramárová, K. Význam a dôležitost' značky pre podnik. GRANT J. 2012, 29-34.

83. Myšková, R.; Hajek, P. Sustainability and Corporate Social Responsibility in the Text of Annual Reports-The Case of the IT Services Industry. Sustainability 2018, 10, 4119. [CrossRef]

84. Pilař, L.; Balcarová, T.; Rojík, S. Farmers' markets: Positive feelings of instagram posts. Acta Universitatis Agriculturae et Silviculturae Mendelianae Brunensis 2016, 64, 2095-2100. [CrossRef]

85. Světlík, J. Integrating online advertising into integrated marketing communications. Mark. Identity 2017, 1, 206-216.

Publisher's Note: MDPI stays neutral with regard to jurisdictional claims in published maps and institutional affiliations. 